\title{
CHARACTERISTICS AND DYES BIODEGRADATION POTENTIAL OF CRUDE LIGNOLYTIC ENZYMES FROM WHITE-ROT FUNGUS CREPIDOTUS VARIABILIS ISOLATED IN COASTAL TANZANIA
}

\author{
GYS Mtui \\ Department of Molecular Biology and Biotechnology, University of Dar es Salaam, \\ P. O. Box 35179, Dar es Salaam, Tanzania. Email: gmtui@amu.udsm.ac.tz
}

\begin{abstract}
Lignocellulosic enzymes from Crepidotus variabilis collected from mangrove forests of coastal Tanzania were investigated by using standard methods, and their ability to degrade aromatic compounds were elucidated. The fungal crude enzyme filtrates had maximum laccase (Lac), lignin peroxidase (LiP) and manganese peroxidase $(\mathrm{MnP})$ activities of $70 \mathrm{U} / \mathrm{mL}, 16 \mathrm{U} / \mathrm{mL}$ and $8, \mathrm{U} / \mathrm{mL}$ respectively. The crude enzyme extracts were able to oxidize rhemazol brilliant blue- $R$ (RBB-R) dye, phenol, $\alpha$-naphthol and pyrogallol. Also, they could remove up to $58 \%$ and $92 \%$ color from raw textile effluent and aromatic dyes, respectively, after 14 days of incubation at $30^{\circ} \mathrm{C}$ and $\mathrm{pH}$ 4.5. Desalted and size-separated enzyme filtrates, resolved by sodium docecyl sulphatepolyacrylamide gel electrophoresis (SDS-PAGE) and isoelectric focusing (IEF), showed laccases and peroxidases from $\mathrm{C}$. variabilis to have molecular weights of $67 \mathrm{kDa}$ and $47 \mathrm{kDa}$, respectively, while the isoelectric points (pI) of laccases and peroxidases were found to lie in a range of 3.0 to 4.1. The study provided basic information on the characteristics of crude lignolytic enzymes from C. variabilis and confirmed it to be one of the potential biodegraders of aromatic compounds that could be applied in bioremediation of polluted ecosystems.
\end{abstract}

\section{INTRODUCTION}

The raw industrial and domestic effluents that are discharged into the Indian Ocean pose a serious environmental pollution problem. Such wastewater contains recalcitrant organic compounds including crude oil wastes and textile effluents; organochloride agrochemicals such as DDT, PCBs and dioxins (Nakamura et al. 1997, 1999, Saparrat 2000, Mtui and Nakamura 2002, Gonzallo et al. 2005). However, Tanzania has rich diversity of basidiomycetes fungi with potential for application in both ex situ and in situ biodegradation of such pollutants (Härkönen et al. 2003, Mtui et al. 2003, Coulibaly et al. 2003, Martinez et al. 2005). Worldwide, there is little published information on lignin-degrading abilities of the obligate and facultative marine fungi, Mtui and Masalu 2008). Moreover, the presence of manganese-dependant peroxidase (MnPs), lignin peroxidases (LiPs) and laccases (Lacs) in such fungi have not been investigated except for few studies (Datta et. al. 1991;
Raghukumar et al. 1999; Kondo et. al. 2004; Mtui and Masalu, 2008). In Tanzania, more attention on fungal research has been focused on edible mushrooms, with more than 50 edible species already identified (Härkönen et al. 2003, Mtui et al. 2003), but research on the non-edible types has so far received little attention.

Crepidotus variabilis (Pers) Gray is a woodinhabiting white-rot fungus, a member of family Crepidotaceae and order Agaricales that is characterized by its saprotrophic habit, filamentous cuticle, and brownpigmented basidiospores that lack either a germ pore or plage (Aime, 2001). Although terrestrial $C$. variabilis has been shown to be able to degrade lipophilic extractives in Eucalyptus globulus wood in solid fermentation (Gutiérrez et al. 1999, Martinez et al. 1999) and lignocellulosic compounds in liquid cultures (Martinez et al. 2005), the C. variabilis strains inhabiting marine ecosystems have not been reported in the literature and their degradative enzymes have 
not been elucidated. Therefore, this knowledge gap in marine and coastal fungal lignocellulosic enzyme profiles, properties and degradative abilities makes it an important and interesting area of research.

Characterization of lignocellulosic enzymes is important in order to identify potential specific isoforms that are suitable for bioremediation purposes. Chromatographical techniques have been shown to be conducive in separating individual proteins into isoenzymes in order to evaluate their properties. The separated fractions are resolved in sodium docecyl sulphatepolyacrylamide gel electrophoresis (SDSPAGE) which is a powerful tool in the analytical separation of macromolecules whereby proteins are separated according to their molecular sizes under the influence of an electric field. On the other hand, isoelectric focusing (IEF) is another biochemical technique in which protein molecules are separated as they migrate through a $\mathrm{pH}$ gradient under a strong electric field (Deutscher 1990). SDS-PAGE analysis has shown that relative molecular weights of extracellular proteins from lignocellulosic fungi range from $40 \mathrm{kDa}$ to $130 \mathrm{kDa}$ (Matsubara et al. (1996), Heinfling et al. (1998), while IEF analysis shows considerable variation in isoelectric point (pI) values between 3 to 10 (Scopes, 1982; Deutscher 1990, Martinez et. al. 2005). There is very limited information available in the literature on the specific characteristics of extracellular ezymes from facultative and marine fungi.

This work reports the original research results on extracellular enzymes from Crepidotus variabilis isolated from Tanzania's marine ecosystem and elucidates their characteristics and dye degradative abilities.

\begin{abstract}
MATERIALS AND METHODS
Study site, sample collection and identification

The fungus was collected at Oyster Bay, Mtoni and Mbweni mangrove forests along the Western Indian Ocean cost of Dar es Salaam, Tanzania. It was found growing on decomposing logs of marine vegetation at the periphery of the seashore. The fungus was identified as Crepidotus variabilis (Pers) Gray based on morphological characteristics (Ainsworth 1973, Arora 1986, Buckzaki 1992, Phillips 1994, Bougher and Katrina 1998, Harkönen et. al. 2003).
\end{abstract}

Culture media and cultivation of mycelia Solid media consisted of 5\% (w/v) malt extract agar (MEA), 1\% glucose, $0.002 \%$ malt extract and $20 \mathrm{~mL}$ of Kirk medium and maintained at $\mathrm{pH} 4.5$ using potassium phthalate buffer (Tien and Kirk, 1984). Cultivation was done in $10 \mathrm{~mm}$ - diameter petri dishes. Fresh $2 \mathrm{~mm}^{2}$ tissues of fungal fruiting bodies were aseptically cultured in the petri dished and incubated at $30^{\circ} \mathrm{C}$ for 5 7 days for production of mycelial mats. The liquid medium contained 1.0-3.0 ammonium tartrate, $1 \%$ glucose and $25 \mathrm{~mL}$ Kirk medium at $\mathrm{pH}$ 4.5. Cultivation in liquid medium was done in $250 \mathrm{~mL}$ conical flasks plugged with cotton wool and then covered with aluminium foil. The culture media was sterilized by autoclaving at $121^{\circ} \mathrm{C}$ for 20 minutes. The flasks were then inoculated with $5 \mathrm{~mm}$ mycelial mats (from solid cultures) and incubated in stationary condition at $30^{\circ} \mathrm{C}$ for up to 2 weeks.

Screening for RBBR decoloration, oxidation of guaiacol, $\alpha$-naphthol and pyrogallol

Solidified 2\% (w/v) MEA plates containing $0.005 \mathrm{~g} / \mathrm{L}$ rhemazol brilliant blue-R RBBR (Sigma, UK) were inoculated with 5-mm agar plugs from a 7 day-old mycelium of C. variabilis previously grown on $2 \%(\mathrm{w} / \mathrm{v})$ MEA. Plates were incubated at $30^{\circ} \mathrm{C}$ in the dark until they were completely colonized. Peroxidases and oxidases production were revealed by the halo in the medium resulting 
from RBBR decolorization. For guaiacol, $\alpha$-naphthol and pyrogallol tests, 7-mm agar plug from 7-day old mycelium grown in 2 $\%(\mathrm{w} / \mathrm{v})$ MEA was used to inoculate triplicate plates with $\mathrm{w} / \mathrm{v} \quad 0.2 \%$ sugarcane bagasse powder, $0.01 \%$ guaiacol and $1.6 \%$ agar. The plates were incubated for 21 days before being evaluated on the basis of the formation of a reddish coloured zone in the culture medium resulting from guaiacol oxidation. The drop-test was then carried out on the same plates using $0.1 \mathrm{M} \alpha$-naphthol and $1 \%(\mathrm{v} / \mathrm{v})$ pyrogallol to detect laccases and peroxides, respectively (Okino et al. 2000).

\section{Decolorization of textile wastewater and aromatic dyes}

Half-strength raw effluent wastewater from Karibu Textile Mill Ltd in Dar es Salaam and $1 \%(\mathrm{w} / \mathrm{v})$ of analytical grade synthetic dyes (Azure-B, Poly-B and Poly-R), were used. The wastewater and synthetic dyes were cultured in a low nitrogen medium. Fungal mycelia were then aseptically inoculated into $250 \mathrm{~mL}$ flask and the reaction mixture was incubated at $30^{\circ} \mathrm{C}$ for 2 weeks. Supernatant of the culture was drawn at 2-day intervals and centrifuged $(18,000 \mathrm{~g}$ for 15 minutes). Control experiments were conducted using the same medium without fungal inocula. The color intensity (absorbance) was determined by using UVVisible Thermo Stonic spectrophotometer, (UK) at the maximum wavelengths $\left(\lambda_{\max }\right.$ of the dyes (Yang et al. 2003).

\section{Sample concentration and dialysis}

Crude enzyme filtrates were successively filtered in $0.45 \mu \mathrm{m}$ and $0.2 \mu \mathrm{m}$ Acrodisc Syringe Filters (Pall Gelman Lab, USA). The $15 \mathrm{~mL}$ samples were concentrated 10fold by ultrafiltration using Microsep devise containing omega membrane (Pall Life Sciences, USA). The samples were centrifuged $(10,000 \mathrm{~g}$ for $3 \mathrm{~h})$ at $4^{\circ} \mathrm{C}$. The Micfrosep devise retained in the reservoir the concentrated proteins of molecular weight larger than $10 \mathrm{kDa}$, while lower molecular weight proteins and solvent passed through the membrane into the filtrate reservoir. The concentrated proteins were stored at $4^{\circ} \mathrm{C}$ for further analysis.

\section{Protein spectrophotometric assay}

The spectrometric assay at $280 \mathrm{~nm}$ wavelength was used to estimate the presence of proteins in the filtrates by measuring UV-visible spectrophotometer (Shimadzu Co. Ltd., Japan). The absorbance of the samples were also determined at $\mathrm{A}_{260}$ to detect the presence of nucleic acids. The protein concentrations were calculated according to the following empirical equation which takes into account the correction of the interference by nucleic acids (Deutscher 1990): Protein concentration $\left.(\mathrm{mg} / \mathrm{ml})=1.55 \mathrm{~A}_{280^{-}} 0.76 \mathrm{~A}_{260}\right)$, where $\mathrm{A}=$ absorbance.

\section{Determination of enzymes activities}

LiP activity was determined spectrophotometrically at $310 \mathrm{~nm}$ through the oxidation of veratryl alcohol to veratryl aldehyde (molar absorptivity, $\varepsilon_{310},=9300$ $\left.\mathrm{M}^{-1} \mathrm{~cm}^{-1}\right)$. The reaction mixture contained $300 \mu \mathrm{L}$ veratryl alcohol $(8 \mathrm{mM}), 600 \mu \mathrm{l}$ sodium tartrate buffer $(0.5 \mathrm{M}, \mathrm{pH} 4.5)$ at 27 $\left.{ }^{0} \mathrm{C}\right), 60 \mu \mathrm{L}$ mycelia liquid fraction and 1890 $\mu \mathrm{L}$ distilled water. The mixture was incubated for 2 minutes at $30^{\circ} \mathrm{C}$ and the reaction was initiated by addition of $150 \mu \mathrm{L}$ $\mathrm{H}_{2} \mathrm{O}_{2} \quad(5 \mathrm{mM})$. The absorbance was immediately measured in one-minute intervals after addition of $\mathrm{H}_{2} \mathrm{O}_{2}$. One unit (U) of LiP activity was defined as activity of an enzyme that catalyzes the conversion of $1 \mu$ mole of veratryl alcohol per minute (Nakamura et al. 1997, 1999).

Activity of $\mathrm{MnP}$ was measured following the method described by Wunch et al. (1997). In this method, guaicol was used as a substrate, and the increase in absorbance at $465 \mathrm{~nm}$ due to oxidation of guaicol was measured $\left(\varepsilon_{465}=12,100 \mathrm{M}^{-1} \mathrm{~cm}^{-1}\right)$. The reaction mixture contained $300 \mu \mathrm{L}$ sodium succinate buffer $\left(0.5 \mathrm{M}, \mathrm{pH} 4.5\right.$ at $\left.27{ }^{\circ} \mathrm{C}\right)$, $300 \mu \mathrm{L}$ guaicol $(4 \mathrm{mM}), 600 \mu \mathrm{L}$ manganese sulphate $(1 \mathrm{mM}), 300 \mu \mathrm{L}$ mycelial liquid 
fraction and $1200 \mu \mathrm{L}$ distilled water. The mixture was incubated for two minutes at 30 ${ }^{\circ} \mathrm{C}$ and the reaction was initiated by addition of $300-\mu \mathrm{L}$ hydrogen peroxide $(1 \mathrm{mM})$. The absorbance was measured immediately at $465 \mathrm{~nm}$ in one-minute intervals after addition of hydrogen peroxide. One unit of $\mathrm{MnP}$ activity was defined as activity of an enzyme that catalyzes the conversion of $1 \mu$ mole of guiacol per minute.

Lac activity was measured by using the method described by Bourbounnais et al. (1995) based on the oxidation of 2,2'azino-bis (3-ethylbenzothiazoline)-6sulphonic acid (ABTS). The rate of ABTS oxidation was determined spectrophotometrically at $420 \mathrm{~nm}\left(\varepsilon_{420}=\right.$ $\left.36,000 \mathrm{M}^{-1} \mathrm{~cm}^{-1}\right)$. The reaction mixture contained $600 \mu \mathrm{l}$ sodium acetate buffer (0.1M, pH 5.0 at $27^{\circ} \mathrm{C}$ ), $300 \mu \mathrm{L}$ ABTS (5 $\mathrm{mM}), 300 \mu \mathrm{L}$ mycelial liquid fraction and $1400 \mu \mathrm{L}$ distilled water. The mixture was incubated for 2 minutes at $30^{\circ} \mathrm{C}$ and the reaction was initiated by addition of $300 \mu \mathrm{L}$ hydrogen peroxide. The absorbance was measured immediately in one-minute intervals after addition of hydrogen peroxide. One unit of laccase activity was defined as activity of an enzyme that catalyzes the conversion of $1 \mu$ mole of ABTS per minute.

\section{Desalting and size separation of extracellular proteins by gel chromatography}

Enzyme desalting and size separation was done by using PD-10 column (void volume $3.5 \mathrm{~mL}$ ) parked with Sephadex $G-25$ dextran gel (Pharmacia, Sweden). The column was equilibrated with $10 \mathrm{mM}$ Bistris [bis(2hydroxyethyl)imino-tris (hydroxymethyl) methane] - $\mathrm{HCl}$ buffer (Bistris- $\mathrm{HCl})(\mathrm{pH}$ 6.5). Culture filtrate sample $(2.5 \mathrm{~mL})$ was passed through the column by $3.5 \mathrm{~mL}$ Bistris-HCl buffer exchange. The eluent was collected and its absorbance at $280 \mathrm{~nm}$ and $260 \mathrm{~nm}$ was determined by UV-Visible spectrophotometer (Shimadzu, Japan).

\section{SDS-PAGE and IEF analyses}

Modified Laemmli (1970) method of SDSPAGE analysis using 30\% acrylamide: $0.8 \%$ bis-acrylamide, $2 \mathrm{M}$ Tris- $\mathrm{HCl}$ buffer $(\mathrm{pH}$ $8.8), 20 \%$ SDS, $0.02 \%\left(\mathrm{NH}_{4}\right)_{2} \mathrm{~S}_{2} \mathrm{O}_{8}$ and 0.01 TEMED was used to resolve the purified proteins. Electrophoresis was carried out at $150 \mathrm{~V}$ and the gel staining was done using $0.05 \%(\mathrm{w} / \mathrm{v})$ coomassie brilliant blue (CBB) $\mathrm{R} 150$ followed by de-staining at $10 \%$ methanol-acetic acid solution.

Isoelectric points (pIs) were determined by using IEF Unit, commercial ampoulines and protein markers (Pharmacia, Sweden) at $\mathrm{pH}$ range of 2.5-9.5. Elecrofocusing was carried out at $1,500 \mathrm{~V}$ and $50 \mathrm{~mA}$ for $1.5 \mathrm{~h}$. The gels were stained by $0.01 \%(\mathrm{w} / \mathrm{v})$ of CBB R 250 followed by destaining in $20 \%(\mathrm{v} / \mathrm{v})$ ethanol-acetic acid, solution (Scopes 1982, Deutscher 1990).

\section{RESULTS AND DISCUSSION \\ Strain description}

The Crepidotus variabilis strain inhabiting dry twigs and decomposing stems of mangroves is kidney-shaped. The white caps, turning creamy with age, are tiny $(0.2$ $-3 \mathrm{~cm}$ in diameter), sessile (lacking stalk) and the attachment to the substrate is via its cap rather than stipe (Fig. 1). The identity of the strain was confirmed by using descriptive keys (Bougher and Katrina, 1998, Aime 2001, Harkönen et. al. 2003). The salt tolerance of $C$. variabilis makes it a potential candidate for bioremediation of high-salt content effluents at alkaline condition and its ability to attach firmly to substrates makes it adaptive to the turbulent seashore environment especially during high tides.

Oxidation of RBB-R, guaiacol, $\alpha-$ naphthol and pyrogallol by $C$. variabilis The ability of $C$. variabilis to degrade aromatic model compounds such as RBB-R and guaiacol in solid medium is shown in Figure 2. Pyrogallol and $\alpha$-naphthol were also oxidized by the fungus. The degradation of the recalcitrant organic 
compounds were evidenced by the appearance of a halo around the $C$. variabilis mycelia. The results imply that the same enzymes could also be used in detoxification of aromatic pollutants such as agroindustrial industrial effluents. The degrading ability of basidiomycetes fungi is thought to be due to the action of their extracellular oxidative enzymes (Wunch et al. 1997, George et al. 2000). The involvement of $\mathrm{LiP}$ and $\mathrm{MnP}$ in degradation of aromatic compounds suggests that hydrogen peroxide is responsible for the breakdown of aromatic molecules and oxygen may play a role in the initial degradation, while Lac and other enzymes interact with mediators during transformation of lignocellulose (Leonowicz et al. 2001). The ex situ degradation of aromatic molecules serves as a model system for in situ bioremediation of marine ecosystems polluted with recalcitrant hazardous chemicals. The results are consistent with the findings by Shin et al. (1997), Okino et al. (2000) and Mtui and Nakamura (2004) who demonstrated that both wood-inhabiting and non-wood inhabiting basidiomycetes fungi are capable of degrading RBB-R dye and other xenobiotic compounds. The decolorization ability is a result of synergetic action of multiple enzymes including peroxidases and oxidases (George et al. 2000).

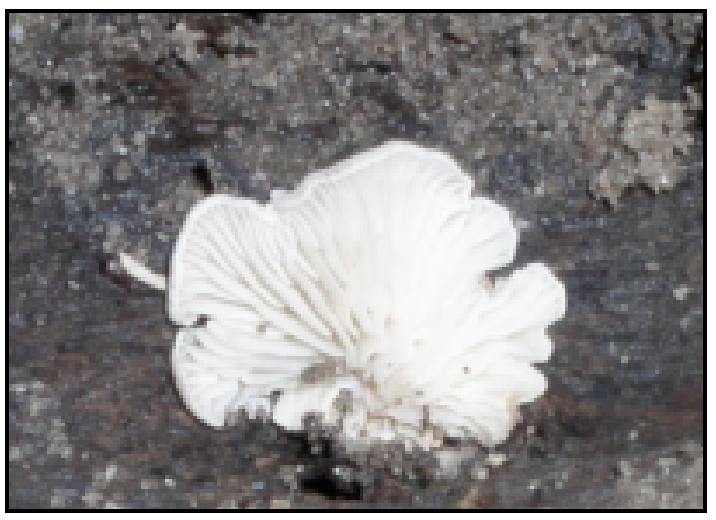

Figure 1: Marine Crepidotus variabilis growing on a base of decomposing log in the mangrove-inhabited sediments. Note the peculiar lack of stalk and attachment to the substrate via its cap.

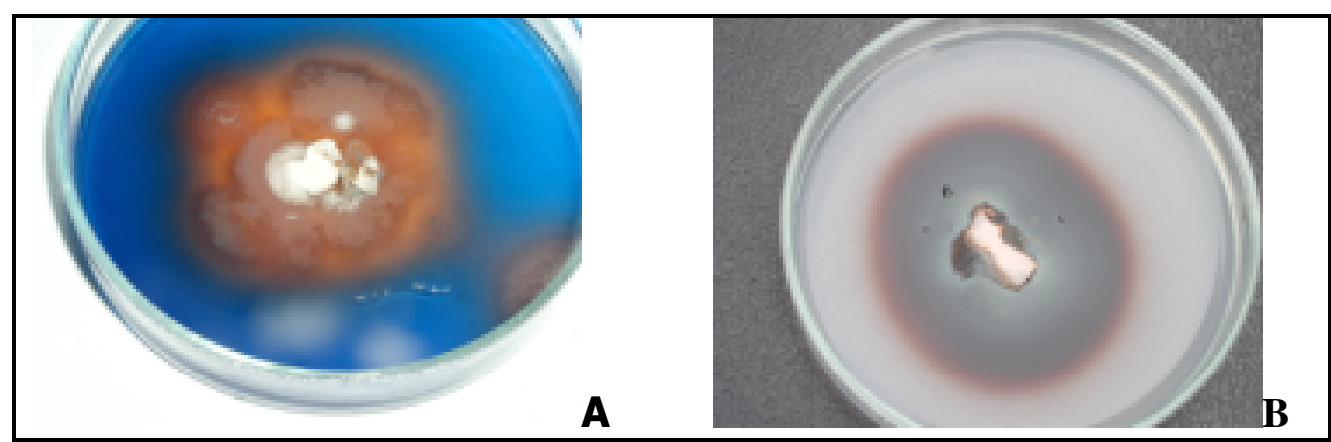

Figure 2. $\quad$ MEA agar plates showing RBB-R decolorization (A) and guaiacol oxidation (B) by Crepidotus variabilis in solid cultures after 5 days of incubation at $30^{\circ} \mathrm{C}$. The substrates were completely oxidized after 14 days of incubation. 
Production of lignocellulosic enzymes Figure 3 shows time courses of lignocellulosic enzymes activities by Crepidotus variabilis. The enzymes were produced during the idiophase when the fungi were carrying out secondary metabolism in nitrogen-deficient condition. Generally, the enzyme production started after 10 days of incubation, increasing sharply from day 11 and peaked at day 12 for Lac and day 13 for Lip and MnP. The maximum Lac, $\mathrm{LiP}$ and $\mathrm{MnP}$ activities were $50 \mathrm{U} / \mathrm{mL}, \quad 10 \mathrm{U} / \mathrm{mL}$ and $8 \mathrm{U} / \mathrm{ml}$, respectively. The decrease in enzyme activities after 12-13 days of incubation could be attributed to the presence of protease which digests proteins in solutions and addition of protease inhibitor in the reaction mixture would solve the problem (Nakamura et al. 1999, Mtui and Nakamura 2002).

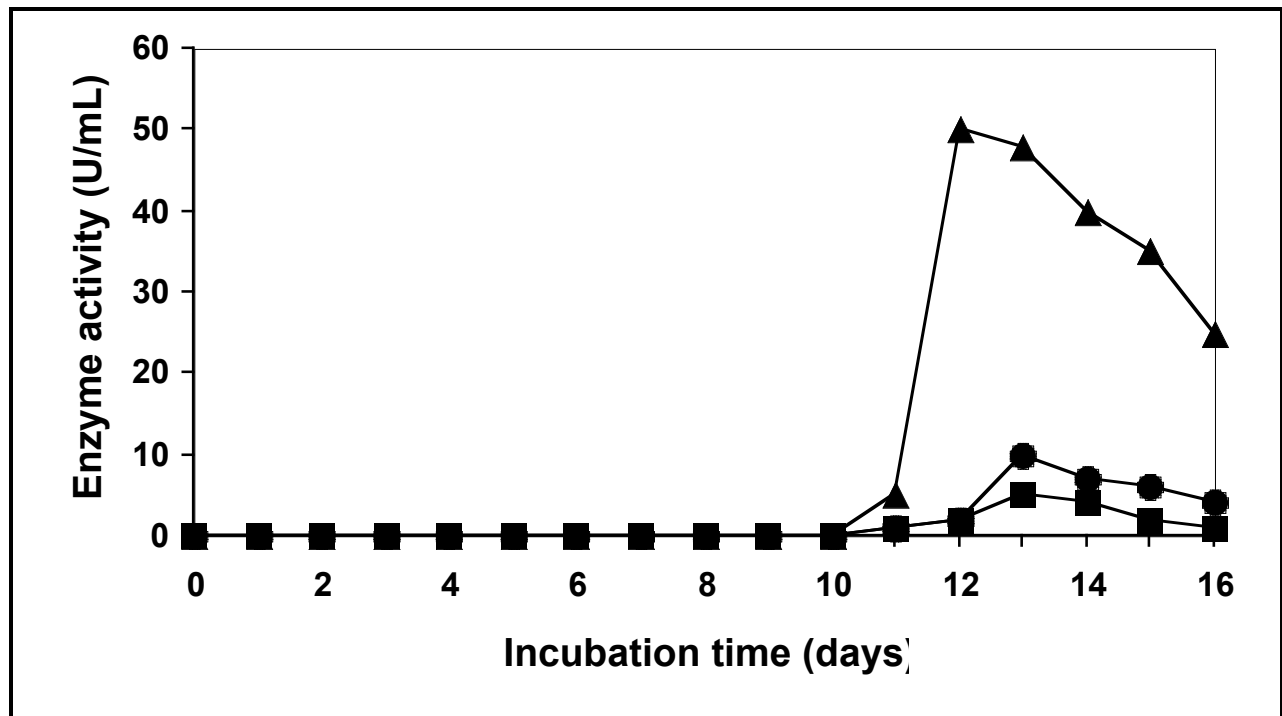

Figure 3: $\quad$ Time courses of lignocellulolytic enzymes production by Crepidotus variabilis grown in Kirk medium at $\mathrm{pH} 4.5$ and temperature of $30^{\circ} \mathrm{C}$. Symbols: Laccase $(\boldsymbol{\Delta})$, Lignin peroxidase ( $\bullet$ ); Manganese peroxidase $(\boldsymbol{\square})$.

The effect of nitrogen content in the culture media was investigated in order to address the problem of prolonged lag phase in enzyme production observed in Figure 3. Media containing 1.0, 2.0 and $3.0 \mathrm{mM}$ ammonium tartrate were used for low nitrogen (LN), medium nitrogen $(\mathrm{MN})$ and high nitrogen $(\mathrm{HN})$ cultures, respectively. As shown in Table 1, LN medium was the most effective in producing larger quantities of extracellular enzymes after shorter incubation periods. Up to $70 \mathrm{U} / \mathrm{mL}$ Lac, 16 $\mathrm{u} / \mathrm{mL} \mathrm{LiP}$ and $8 \mathrm{U} / \mathrm{ml} \mathrm{MnP}$ was produced maximally after 8 days of incubation. At $\mathrm{HN}$ medium, comparatively lower enzyme production peaking after 15 days of inhibition was observed. This trend could be attributed to the fact that at high nitrogen concentration, fungal mycelial growth is favored as the culture exhibits mostly primary metabolic activities (Nakamura et. al. 1999). The results were consistent with the work by Raghukumar et al. (1999) and Kondo et al. (2004) who demonstrated the 
ability of some coastal and marine fungi to produce major lignocellulolytic enzymes at various culture growth conditions. The amounts of Lac, LiP and MnP are comparable to the amounts produced by the Tanzania's terrestrial fungi (Mtui et al. 2003, Mtui and Nakamura 2004). The presence of all major lignocellulosic ezymes, namely Lac, Lip and MnP in C. variabilis underlines its degradation potential for cellulose, lignin and other organic compounds. Since the amounts of LiP and $\mathrm{MnP}$ produced are comparatively low, it is suggested that for improved enzyme production, further research should focus on improvement of culture growth conditions including addition of potential LiP and $\mathrm{MnP}$ inducers.

Table 1: Effect of nitrogen content on the production of extracellular enzymes by Crepidotus variabilis in $1 \%$ glucose medium containing Kirk's Salts.

\begin{tabular}{|c|c|c|c|c|c|c|c|c|c|}
\hline \multirow{3}{*}{$\begin{array}{l}\text { Incubation } \\
\text { time (days) }\end{array}$} & \multicolumn{9}{|c|}{ Enzyme activity (U/ml) } \\
\hline & \multicolumn{3}{|c|}{ Laccase } & \multicolumn{3}{|c|}{ Lignin peroxidase } & \multicolumn{3}{|c|}{ Manganese peroxidase } \\
\hline & $\mathrm{LN}$ & $\mathrm{MN}$ & $\mathrm{HN}$ & $\mathrm{LN}$ & $\mathrm{MN}$ & $\mathrm{HN}$ & $\mathrm{LN}$ & $\mathrm{MN}$ & $\mathrm{HN}$ \\
\hline 1 & 0 & 0 & 0 & 0 & 0 & 0 & 0 & 0 & 0 \\
\hline 2 & 0 & 0 & 0 & 0 & 0 & 0 & 0 & 0 & 0 \\
\hline 3 & $0.2 \pm 0.1$ & 0 & 0 & 0 & 0 & 0 & 0 & 0 & 0 \\
\hline 4 & $4.7 \pm 0.3$ & 0 & 0 & 0 & 0 & 0 & 0 & 0 & 0 \\
\hline 5 & $15.6 \pm 2.4$ & 0 & 0 & $0.3 \pm 0.2$ & 0 & 0 & $0.4 \pm 0.2$ & 0 & 0 \\
\hline 6 & $35.9 \pm 6.7$ & 0 & 0 & $0.6 \pm 0.3$ & 0 & 0 & $1.7 \pm 0.5$ & 0 & 0 \\
\hline 7 & $67.4 \pm 11.0$ & 0 & 0 & $1.8 \pm 0.9$ & 0 & 0 & $3.7 \pm 1.2$ & 0 & 0 \\
\hline 8 & $70.0 \pm 13.1$ & 0 & 0 & $15.9 \pm 3.6$ & 0 & 0 & $7.7 \pm 2.1$ & 0 & 0 \\
\hline 9 & $52.1 \pm 9.3$ & 0 & 0 & $11.3 \pm 1.9$ & 0 & 0 & $6.2 \pm 1.6$ & 0 & 0 \\
\hline 10 & $43.6 \pm 9.1$ & 0 & 0 & $9.8 \pm 1.1$ & 0 & 0 & $4.3 \pm 1.0$ & 0 & 0 \\
\hline 11 & $31.7 \pm 4.4$ & $5.2 \pm 2.2$ & 0 & $6.2 \pm 0.8$ & $1.2 \pm 0.6$ & 0 & $4.0 \pm 0.8$ & $0.5 \pm 0.1$ & 0 \\
\hline 12 & $21.8 \pm 3.3$ & $50.3 \pm 9.1$ & 0 & $5.3 \pm 1.0$ & $2.3 \pm 0.5$ & 0 & $2.3 \pm 0.4$ & $1.5 \pm 0.2$ & 0 \\
\hline 13 & $22.1 \pm 3.0$ & $48.4 \pm 7.7$ & $0.9 \pm 0.2$ & $3.9 \pm 0.8$ & $9.9 \pm 1.7$ & $0.2 \pm 0.1$ & $2.1 \pm 0.5$ & $5.2 \pm 1.7$ & 0 \\
\hline 14 & $19.2 \pm 2.6$ & $40.7 \pm 5.3$ & $6.2 \pm 1.3$ & $3.0 \pm 0.8$ & $7.6 \pm 1.4$ & $1.1 \pm 0.3$ & $0.8 \pm 0.3$ & $4.1 \pm 1.9$ & $1.7 \pm 0.2$ \\
\hline 15 & $14.7 \pm 2.1$ & $35.1 \pm 4.9$ & $15.8 \pm 3.3$ & $2.8 \pm 0.4$ & $6.0 \pm 1.1$ & $6.2 \pm 1.2$ & $0.5 \pm 0.2$ & $3.4 \pm 1.1$ & $2.6 \pm 1.1$ \\
\hline 16 & $10.8 \pm 1.9$ & $15.2 \pm 2.3$ & $8.7 \pm 2.1$ & $2.2 \pm 0.5$ & $3.9 \pm 0.6$ & $5.4 \pm 0.9$ & $0.2 \pm 0.1$ & $1.5 \pm 0.6$ & $1.9 \pm 1.0$ \\
\hline
\end{tabular}

Low nitrogen (LN), medium nitrogen $(\mathrm{MN})$ and high nitrogen $(\mathrm{HN})$ medium contained 1.0, 2.0 and 3.0 $\mathrm{mM}$ ammonium tartrate, respectively. Each value is an average of triplicate cultures \pm standard deviation

\section{Decolorization of textile effluent and synthetic dyes}

Figure 4 shows the effect of the crude enzymes from Crepidotus variabilis in decolorization of 1:1 diluted raw wastewater and synthetic aromatic dyes cultured in low nitrogen medium It was found that the fungus could decolorize the half-strength raw wastewater by $58 \%$ after 14 days of incubation. In the case of $1 \%$ synthetic azo dyes, color removal from Azure-B, Poly-B, and Poly-R were $84 \%, 86 \%$ and $92 \%$, respectively after 2 weeks of incubation. The decolorization of azo dyes in the absence of a redox mediator shows that the Lac, LiP and $\mathrm{MnP}$ from $C$. variabilis have broad substrate range (Yesilada 1995, Yang et al. 2003). The results are consistent with the findings by Gutiérrez et al. (1999) and Martinez et al.(1999, 2005) who reported the degradative abilities of white-rot fungi on recalcitrant organic substrates. Colour removal by filamentous fungi has been attributed to be mainly due to biosorption to the mycelium (Yang et al. 2003), but Leonowicz et al. (2001) and Gonzalo et al. (2005) have shown that Lac, LiP and MnP are capable of carrying out catalytic and freeradical mediated breakdown of aromatic compounds including ring cleavage. The fact that degradative enzymes from $C$. variabilis could not degrade all the organic compounds 
in the wastewater shows the complexity of systems associated with the degradation of aromatic molecules. As lignocellulosic enzymes work in concert with other fungal enzymes (Leonowickz et al. 2001), a synegistic action of enzymes from different fungal strains is therefore imperative for complete degradation of recalcitrant organic compounds.

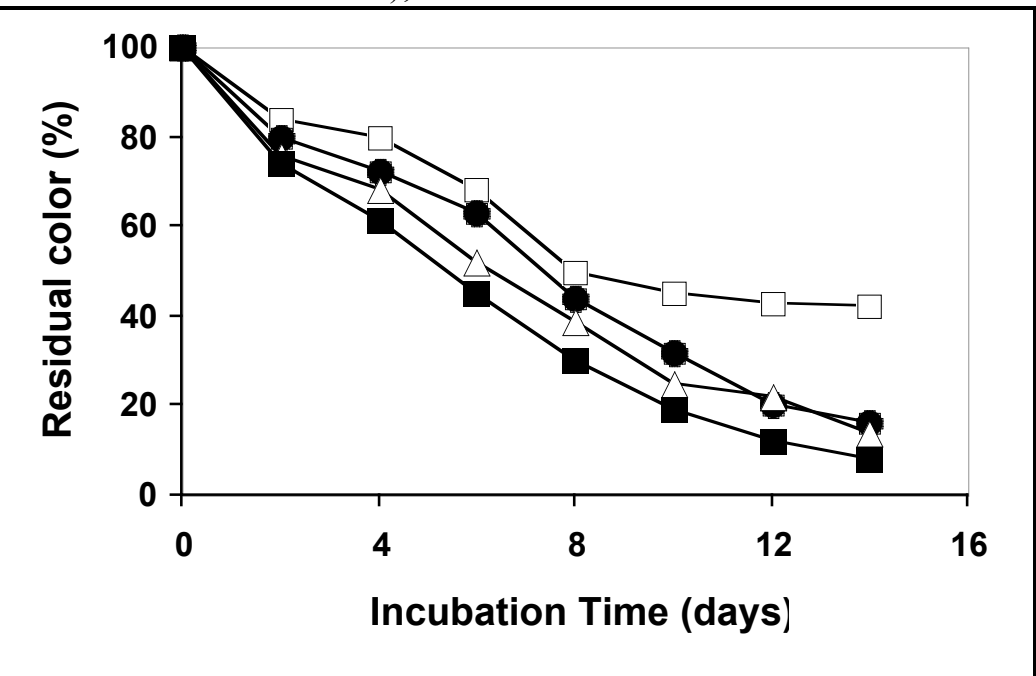

Figure 4: Decolorization of half-strength textile wastewater and $1 \%$ synthetic dyes by Crepidotus variabilis grown on low nitrogen medium at $30^{\circ} \mathrm{C}$ and $\mathrm{pH} 4.5$. Symbols: Textile wastewater $(\square)$, Azure-B ( $\bullet)$, Poly-B $(\Delta)$, Poly-R ( $\mathbf{\square})$.

\section{Characterization of extracellular enzymes from Crepidotus variabilis}

The filtrates of $C$. variabilis concentrated by ultrafiltration and subjected to spectrophotometric analysis at 280 and 260 $\mathrm{nm}$ had overall protein content of 4.3 $\mathrm{mg} / \mathrm{ml}$. In Figure 5, SDS-PAGE analysis showed distinct bands at relative molecular weights of $67 \mathrm{kDa}$ and $47 \mathrm{kDa}$, which corresponds to laccases and peroxidases, respectively (Wang and $\mathrm{Ng}, 2006$ ). A minor band resolved at $55 \mathrm{kDa}$ could be an isoform of laccase. The results are comparable to studies by Karhunen et al. (1990), Bonarme et al. (1990), Matsubara et al. (1996) and
Heinfling et al. (1998) who observed the molecular weights of peroxidases from Phlebia radiata, IZU 154, Phanerochaete chrysosporium and Bjerkandera adusta to be $49 \mathrm{kDa}, 43 \mathrm{kDa}, 42 \mathrm{kDa}$ and $45 \mathrm{kDa}$, respectively. Fungal laccases have been shown to have various relative molecular weights as follows: PM1 (CECT2971 Strain - $64 \mathrm{kDa}$ (Coll et al. 1993); Phenerochaete flavido alba - $96 \mathrm{kDa}$ (Perez et al. 1996), Panaeolus sphincrinus and Trametes gallica - $60 \mathrm{kDa}$ (Heinzkill et al. 1998, Dong and Zang 2004, Trametes trogii - $70 \mathrm{kDa}$ (Garzillo et al. 2004) and Ganoderma lucidum - $75 \mathrm{kDa}$ (Wang and $\mathrm{Ng}$ 2006). 


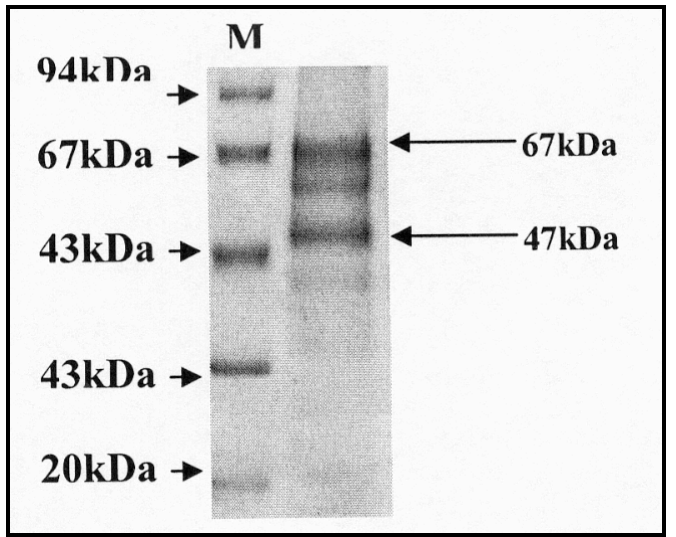

Figure 5: $\quad$ SDS-PAGE analysis of enzymes filtrate from Crepidotus variabilis containing 0.2 $\mathrm{mg} / \mathrm{mL}$ proteins separated by gel filtration chromatography. Main bands appears at $67 \mathrm{kDa}$ (laccases), and $47 \mathrm{kDa}$ (peroxidases). A minor band of laccase isoenzyme was focused at pI 50. (Lane M: Standard Molecular Marker proteins: Phosphorylase b (94 kDa), Bovine Serum Albumin (67kDa), Ovalbumin (43 kDa) and Carbonic Anhydrase $(30 \mathrm{kDa})$.

IEF analysis demonstrated distinctive bands focused at a range of 3.0 to 4.1 , typical of fungal peroxidases and laccases (Fig. 6). Some smaller non-distinctive bands showed up at pI 3.0-3.5 and more minute bands fixed around pI5.3. When broad markers (pI3.5-9.5) were attempted, there was no any band fixed in the basic region. The low pI values indicate that the number of acidic groups in the structures of lignocellulosic enzymes from $C$. variabilis exceeds the number of basic groups. The IEF values for fungal laccases are comparable to the value of pI 3.5 reported by Perez et al. (1996) for $P$. flavido-alba and pI 3.1 reported by Dong and Zang (2004) for T. gallica. Peroxidases from $P$. radiata have been shown to have $\mathrm{pI}$ values ranging from 3.8 to 4.7 (Vares et. al. 1995, Karhunen et al. 1990), while Matsubara et al. (1996) recorded $\mathrm{pI}$ values of 4.9 to 5.1). The next stage of this research will involve purification of the enzymes using ion exchange chromatography including high performance liquid chromatography (HPCL) in order to completely separate individual enzymes and their isoforms.
In the present study, crude lignocellulosic enzymes from white-rot fungus Crepidotus variabilis, collected from Oyster Bay, Mtoni and Kunduchi mangrove forests along the coast of Dar es Salaam, Tanzania have been shown to exhibit maximum Lac, LiP and $\mathrm{MnP}$ activities of $70 \mathrm{U} / \mathrm{mL}, 16 \mathrm{U} / \mathrm{mL}$ and $8 \mathrm{U} / \mathrm{mL}$, respectively, in low nitrogen medium. The enzymes were able to oxidize RBB-R dye, phenol, $\alpha$-naphthol and pyrogallol. Also, the enzymes could decolorize $59 \%$ of raw textile wastewater and up to $92 \%$ synthetic azo dyes. SDS-PAGE analysis showed major bands of concentrated enzymes from $C$. variabilis at relative molecular weights of $67 \mathrm{kDa}$ and $47 \mathrm{kDa}$ for laccases and peroxidases, respectively. IEF analysis revealed that $C$. variabilis produce acidic laccases and peroxidases, the main bands focusing at pI 3.8, 4.0 and 4.1. The study provided basic information on lignocellulosic enzyme profiles from facultative marine $C$. variabilis and elucidated its potential for environmental bioremediation. Optimized enzymes production and purification of fractionalized isoforms to determine their specific characteristics is the focus of future studies. 


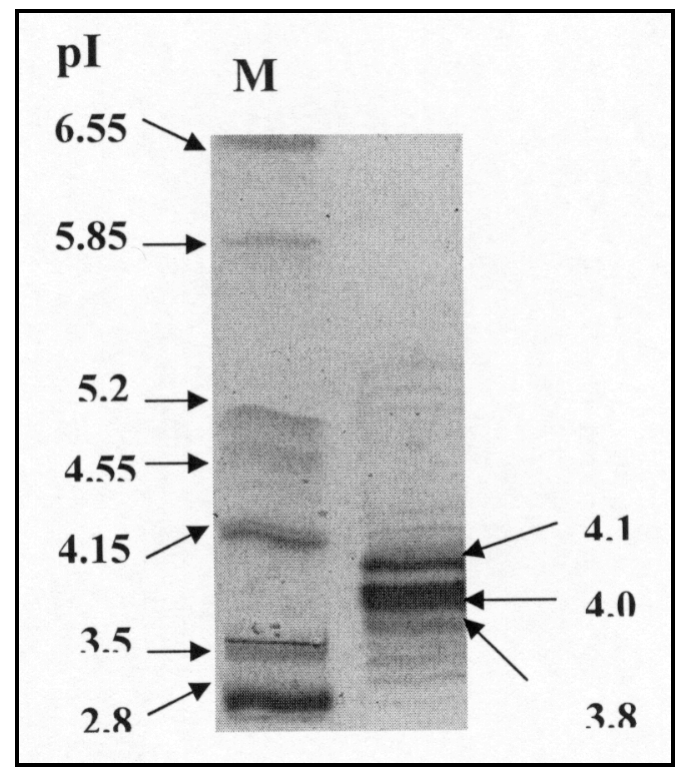

Figure 6: IEF of size-separated C. variabilis enzymes filtrate containing $0.2 \mathrm{mg} / \mathrm{mL}$ proteins separated by gel-filtration chromatography. Main peroxidase and laccase bands appeared at pI 3.8, 4.0 and 4.1 and other smaller bands were focused between pI3.0 and pI3.5. Markers (M): Pepsinogen (pI 2.8), amyloglucosidase (pI 3.5), Glucose oxidase 4.15, soybean trypsin inhibitor (pI 4.55), $\beta$-lactoglobulin A (pI 5.2), bovine carbonic anhydrase B (pI 5.85) and human carbonic anhydrase B (pI 6.55).

\section{ACKNOWLEDGEMENTS}

Major part of this research was carried out with the financial support from Western Indian Ocean Marine Science Association (WIOMSA), through the Marine Research Grant (MARG-1) program. I am grateful to the management of the University of Dar es Salaam through the Department of Molecular Biology and Biotechnology for logistical support. Ms. Rose Masalu is acknowledged for her expert execution of fungal cultivation and crude enzyme assays. Prof. Gunnar Johansson of the Department of Biochemistry and Organic Chemistry at Uppsala University, Sweden, is thanked for his kind facilitation and guidance on protein characterization. My family is appreciated for their warm moral support.

\section{REFERENCES}

Aime MC 2001. Biosystematic Studies in Crepidotus and the Crepidotaceae
(Basidiomycetes, Agaricales) PhD Dissertation, Virginia State University. 194pp.

Ainsworth GC 1973. Introduction to keys of higher taxa. In Ainsworth, G.C., Spoallow F.K. \& Susman, A.S. (Eds.) The fungi Advanced Treatise. Acad. press NY and London. 1-7pp.

Arora D 1986. Mushrooms demystified. Ten Speed Press Berkeley. 959pp.

Bonarme P and Jeffries TW 1990. Selective production of extracellular peroxidases from Phanerochaete chrysosporium in an airlift bioreactor. J. Ferm. Bioeng. 70 (3): 158-163.

Bougher NL and Katrina S 1998. Fungi of Southern Western Australia. Univ. Press. 360 pp.

Bourbounnais R, Paice MG, Reid ID, Lanthier P. and Yaguchi M 1995. Lignin oxidation by laccase isoenzymes 
from Trametes versicolor. Appl. Environ Microbiol.61, 1876-1880.

Buczacki S 1992. Collins Guide mushroom and toadstools of Britain and Europe. Harper Collins Publishers. Glasgow. 2438pp.

Coll PM, Fernanandez JM, Villanueva JR, Santamaria R and Perez P 1993 Purification and characterization of laccase from lignin-degrading basidiomycete PM1 (CECT 2971). Appl. Environ. Microbiol. 59(8): 26072613.

Coulibaly L, Gourene G, Agathos NS 2003. Utilization of fungi for biotreatment of raw wastewaters. Afri. J. Biotechnol. 2(12) 620-630.

Datta A, Bettermann A and Kirk TK 1991. Identification of a specific managanese peroxidase among lignolytic enzymes secreted by Phanerochaete chrysosporium during wood decay. Appl. Environ. Microbiol. 57(5): 14531460.

Deutscher MP 1990. Guide to Protein Purification: Methods to Enzymology. Acad. Press Inc., London. 894 pp.

Dong JL and Zang YZ 2004. Purification and characterization of two laccase isoenzymes from lignolytic fungus Trametes gallica. Prepeparative Biochem. Biotechnol. 34(2): 179-194.

Garzillo AMV, Colao MC, Caruso C, Caporale C, Celletti D and Buonocore V 2004. Laccase from white-rot fungus Trametes trogii. Appl. Microbiol. Biotech. 49(5):545-551.

George PC, Susan K, and Brouse TM 2000. Screening fungi isolated from woody compost for lignin-degrading potential. Compost Sci. Util. 8: 6-11.

Gonzalo R, Tortella A, Cristina M, Diez A and Durán NA 2005. Fungal diversity in decomposition of environmental pollutants. Crit. Rev. Microbiol. 31(4): $197-212$.

Gutiérrez A, del Río JC, Martínez MJ and Martínez, AT 1999. Fungal degradation of lipophilic extractives in Eucalyptus globulus. Appl Environ Microb. 65( 4 ): 1367-1371.

Härkönen M, Niemelä T and Mwasumbi L 2003. Tanzania Mushrooms: Edible, Harmful and other Fungi. Finish Museum of Natural History, Helsinki Karstenia. 35:. Helsinki 200 pp.

Heinfling A, Martinez MJ, Martinez AT, Bergbauer M and Szewzy U 1998 Purification and characterization of peroxidases from the dye-decolorizing fungus Bjerkandera adusta. FEMS Microbiol. Lett. 165: 43-50.

Heinzkill M, Bech L, Halkier T, Scneider M and Anke T 1998 Characterization of laccases and peroxidases from wood rotting fungi (Family Coprinaceae). Appl. Environ. Microbiol. 64(5): 16011606.

Karhunen E, Kantelinen A and Niku-Paavola ML 1990 Mn-dependent peroxidase from lignin-degrading white-rot fungus Phlebia radiata. Arch. Biochem. Biophys. 279(1):25-31.

Kondo R, Daikoku C, Suhara H and Tsutsumi Y 2004. Characterization and expression of manganese peroxidise produced by halotolerant white-rot fungus Phlebis Sp. Mg-60. Proc. $9^{\text {th }}$ Intl. Conf. on Biotechnol. in the pulp \& paper Industry, Durban SA. 111-112pp.

Laemmli UK 1970 Cleavage of structural proteins during the assembly of the head of the bacteriophage T4. Nature (London) 227:680-685.

Leonowicz A, Cho NS, Luterek J, Wilkolazka A, Wojtas WM, Matuszewska A, Hofrischter M, Wesenberg D and Rogalski R 2001. Fungal laccase: properties and activity on lignin. J. Basic. Microbiol. 41(3-4): 185-227.

Matsubara M, Suzuki J, Deguchi T, Miura $M$, and Kitaoka Y 1996. Characterization of peroxidase from the hyperlignolytic fungus IZU-154. Appl. Environ. Microbiol. 62(11):4066-4072.

Martínez MJ, Barrasa JM, Gutierrez A, del Río JC and Martínez, AT 1999. Fungal screening for biological removal of 
extractives from Eukalyptus globulus wood. Can. J. Bot. 77:1513-1522.

Martínez AT, Speranza M, Ruiz-Dueñas FJ, Ferreira $\mathrm{P}$, Camarero S, Guillén F, Martínez, MJ, Gutiérrez A and José C 2005 Biodegradation of lignocellulosics: Microbial, chemical and enzymatic aspects of the fungal attack of lignin. Int. Microbiol. 8: 195-204.

Mtui G. and Nakamura Y 2002 Continuous Production of Lignin-Degrading Enzymes by Bjerkandera adusta Immobilized on PUF. Biotechnol. Lett. 24: 1743 - 1747 .

Mtui GYS, Kivaisi AK and Masalu R 2003 Production of Lignin-degrading Enzymes from Native Tanzanian Mushrooms. Proc. $2^{\text {nd }}$ Intl. Conf. Med. Mushrooms. Pattaya, Thailand. 17-19 July 2003. p 163 - 169.

Mtui $G$ and Nakamura Y 2004 Lignindegrading enzymes from mycelial cultures of basidiomycetes fungi. $J$. Chem. Eng. Japan 37 (1): 113-118.

Mtui G and Masalu R 2008 Extracellular enzymes from brown-rot fungus Laetiporus sulphureus isolated from mangrove forests of coastal Tanzania. Sci. Res. Essays 3(4): 154-161.

Nakamura Y, Mtui G, Sawada T and Kuhawara M, Ito H 1997 Lignin peroxidase Production by Phanerochaete chrysosporium immobilized on polyurethane Foam. J. Chem. Eng. Japan, 30 (1): 1-6.

Nakamura Y, Mtui GYS, Sawada T and Kuwahara M 1999 Lignin-degrading enzyme production from Bjerkandera adusta immobilized on polyurethane foam. J. Biosci. Bioeng: 88 (1), 41-47.

Okino LK, Machado KMG, Fabric $\mathrm{C}$ and Bonomi VLR 2000. Ligninolytic activity of tropical rainforest basidiomycetes. World J. Microbiol. Biotech. 16: 889-893.

Perez,J, Martinez J and Rubia T 1996 Purification and characterization of laccase from white rot fungus Phanerochaete flavido-alba. Appl. Environ. Microbiol. 62(11): 4263-4267.
Phillips R 1994 Mushrooms of Great Britain and Europe. Macmillan. London. 222pp.

Raghukumar C, D'souza TM, Thorn RG, and Reddy CA 1999 Lignin modifying enzymes of Flavodon flavus a basidiomycete isolated from a coastal marine environment. Appl. Environ. Microbiol. 65(5):2103-2111.

Saparrat MCN, Martinez MJ and Tournier HA 2000 Production of ligninolytic enzymes by fusarium solani strains. World J. Microbiol. Biotechnol. 16: 799-803.

Scopes RK 1982 Protein Purification: Principles and Practice. Springer Verlag. 282pp.

Shin KS, Oh IK, and Kim CJ 1997 Production and purification of rhemazol brilliant blue $\mathrm{R}$ decolorizing peroxidase from culture filtrate of Pleurotus ostreatus. Appl. Environ. Microbiol. 63(5):1744-1748.

Tien M and Kirk TK 1984 Lignin-degrading enzymes from Phanerochaete chrysosporium. Purification, characterization and catalytic properties of unique $\mathrm{H}_{2} \mathrm{O}_{2}$-requiring oxygenase. Proc. Natl. Acad Sci USA 81: 22802284.

Vares T, Kalsi M and Hatakka A 1995 Lignin peroxidase, manganese peroxidase and other lignolytic enzymes produced by Phlebia radiata during solid state fermentation of wheat straw. Appl. Environ. Microbiol. 61(10): 3515-3520.

Wang, HX and Ng TB 2006 A laccase from the medicinal mushroom Ganoderma lucidum. Appl. Environ. Microbiol. 72: 508-513.

Wunch KG, Feibelman T and Bennett JW 1997 Screening for fungi capable of removing benzo[a]pyrene in culture. Appl. Microbiol. Biotechnol. 47(5): 620624.

Yang QY, Yang M, Pritsch K, Yediler A, Hagn A, Scloter M and Kettrup A 2003. Decolorization of synthetic dyes and production of manganese-dependent 
peroxidases by new fungal isolates. Biotechnol. Lett. 25:701-713.
Yesilada O 1995 Decolorization of crystal violet by fungi. World J. Microbiol. Biotechnol. 11(5): 601-602. 